Job spells, employer spells, and wage returns to tenure

Paul J. Devereux

Robert A. Hart

J. Elizabeth Roberts

Stirling Economics Discussion Paper 2013-01

January 2013

Online at

http://www.management.stir.ac.uk/research/economics/workingpapers 


\title{
Job spells, employer spells, and wage returns to tenure
}

\author{
Paul J. Devereux ${ }^{1}$, Robert A. Hart ${ }^{2}$, J. Elizabeth Roberts ${ }^{3}$
}

December 2012

JEL Classification: J31, J24

Keywords: Job spells, employer spells, wage-tenure profiles

We show that the distinction between job spells and employer spells matters for returns to tenure. Employer spells encompass between-job wage movements linked to promotions or demotions while job spells don't. Using a 1\% sample of the British workforce over the period 1975-2010, we find that a significant proportion of the return to employer tenure arises due to job changes within employer spells. Conditional on tenure with employer, the return to job tenure is negative. This suggests that any positive effects of job-specific human capital on wage growth within jobs are outweighed by the effects of job changes within firms.

Acknowledgements: We are grateful to the Secure Data Services for granting and facilitating access to the New Earnings Survey Panel Dataset (NESPD) and the Annual Survey of Hours and Earnings (ASHE). We thank Mirko Moro, Sascha Becker and Bob Topel for helpful comments.

\footnotetext{
${ }^{1}$ University College Dublin, IZA and CEPR (devereux@ucd.ie)

${ }^{2}$ University of Stirling and IZA. (r.a.hart@stir.ac.uk)

${ }^{3}$ University of Stirling.
} 


\section{Introduction}

There is a large literature that has studied whether wages increase with tenure with a particular employer. A central feature has been discussion of the best econometric methodology to deal with the endogeneity of tenure with employer. There has also been some interest in whether apparent returns to employer tenure arise because of its correlation with industry or occupation experience. However, the literature has generally ignored the distinction between tenure with employer and tenure on a particular job with an employer.

When studying real wage determination of workers within companies, one can focus on wage dynamics within each internal job spell or over an employer spell that potentially includes multiple jobs in the same firm. When tenure is treated as job-specific, tenure length returns to zero at the point of job change whether the new job is with the same employer or with a new employer. This contrasts with employer tenure where tenure length returns to zero each time an individual changes companies.

If job spells are used as the unit of measurement, then wage changes between jobs are excluded by definition. With employer spells, between-job wage movements linked to internal promotions or demotions play a role. It follows that wage growth during employer spells may diverge from that based on job spells. Moreover, labor market explanations of the underlying causes of wage growth associated with duration of either job or employer spells may also diverge. This paper studies the relationship between real wages and employment tenure in both job and employer spells.

A worker may, over time, undertake one or more jobs with the same employer. Each defined job will typically encompass a set of interrelated job tasks. Given the emphasis on tenure with employer, the empirical literature has concentrated largely on firm-specific human capital. However, as emphasized by Gibbons and Waldman (2004), job-task specific 
human capital may importantly derive from work experience on particular jobs. The individual learns to become more proficient in a set of tasks defined under each constituent job title. ${ }^{4}$

On average, we might expect that individuals who change jobs gain from their moves (Topel, 1991). A critical consideration is that wage returns to employer spells encompass wage rises at the points of internal job changes while wage returns to individual jobs do not. In this paper, we show that a significant proportion of the estimated return to employer tenure arises because of job changes within firms. Whether job changes to higher level jobs represent rewards for job-task performance in the previous job or opportunities for selected individuals to extend firm-level knowledge and experience, the incremental returns at the points of job change are necessarily credited to employer spells rather than job spells. We also find that, conditional on employer tenure, there is no evidence that staying longer in a particular job leads to higher wages. One reason for this relative outcome is that, to the extent that within-job performance reflects ability, weaker performers are more likely to remain longer at lower job levels. This effect dominates any positive effect of job-specific human capital on wage growth within job spells.

The structure of this paper is as follows: In the next section, we describe how models of task-specific human capital and promotions relate to returns to employer and job tenure. Section 3 describes the data and Section 4 outlines the empirical methodology. The results are presented in Section 5 and Section 6 concludes.

\footnotetext{
${ }^{4}$ Specificity does not necessarily derive from unique qualities of employer-level or job-level functions. Lazear (2009) emphasises that employer-specificity can arise even if no particular skill is unique to the employer so long as the particular combination of skills required differs across firms. Analogously, job-specific skills may result from the combination of task requirements in a particular job differing from that required by other jobs in the same firm.
} 


\section{Job spells, employer spells, wages, and tenure}

The literature has highlighted several possible mechanisms that support the common observation that wages rise with tenure. First, there are theories of wages, productivity growth, and turnover behavior that emphasize the role of worker-financed investments in firm-specific capital (Becker 1962; Parsons, 1972). Second, there are models that stress the use of deferred compensation as an incentive mechanism (Lazear, 1979; Becker and Stigler, 1974). In these models, wages increase with tenure even if productivity does not. Third, there are models whereby upward-sloping wage profiles result from insurance considerations (Harris and Holmstrom, 1982) and models where deferred wages are used as a sorting mechanism designed to attract high ability applicants (Salop and Salop, 1976; Guasch and Weiss, 1980). Finally, there are models that emphasize that employees may prefer upwardsloping wage profiles and it may be efficient for firms to facilitate this preference (for example, Frank and Hutchens 1993).

Most of these mechanisms are not relevant to wage profiles within jobs once one controls for tenure with the firm. Incentive mechanisms are most naturally thought of at the firm level and should be determined by employer tenure. Likewise, insurance arrangements are likely to be specific to the employer-employee match and sorting models are probably designed to attract workers to the firm rather than to a particular job in the firm. Additionally, if workers have preferences for higher wages over time, this should show itself in terms of higher pay as firm tenure increases. An exception is task-specific human capital. This is far more linked to individual jobs and should therefore naturally result in a positive return to job tenure as proficiency at job tasks improves.

Many jobs involve a mix of skills contributing both to employer-based and job-based human capital. Employer-specific human capital refers to skills that relate to the workings of an organization at a broader level. Such skills may not be independent of within-job tasks, 
however. Skills in higher-level jobs may utilize or build on skills acquired at lower levels. ${ }^{5}$ An advantage is that this reduces the rate of depreciation of task-specific know-how linked to internal job mobility (Gibbons and Waldman, 2004). Also, interactive skills and knowledge of the roles and inputs of team members within a firm are typically associated with employerspecific capital. ${ }^{6}$ Specificity derives from the fact that it is difficult to replicate in alternative employments the set of individual work attributes that contribute to any given team's performance (Doeringer and Piore, 1971). But team effort may also involve shared taskspecific human capital. For example, cross-functional quality circles involve workers, who are undertaking different, though interdependent, job functions, meeting to analyze and to solve common problems that impinge across functions. This involves acquiring understanding of job tasks that a worker may not directly undertake as part of his own job description.

To the extent that job-task specific human capital matters, it follows that measuring wage returns to tenure necessarily involves distinguishing between returns to job spells and returns to employer spells. One crucial consideration is the internal movement of workers between jobs. Where jobs largely involve acquiring firm-specific human capital, job changes may in part reflect a desire by the worker and the employer to extend the scope of firmrelated knowledge with associated increased expected returns. Promotion to higher level tasks may also be used by the employer to encourage workers to acquire specific know how that is

\footnotetext{
${ }^{5}$ The job of a production manager - encompassing the scheduling, co-ordination, and monitoring of human and material resources to produce goods and services efficiently - implies a need to acquire knowledge and understanding of constituent sections of the enterprise as well as their interconnectedness. Achieving requisite knowledge will entail both task-specific and firm-specific knowledge. As a worker progresses through the company's jobs hierarchy, task-specific skills will be acquired on the job. Firm-specific human capital accrual will result from accumulated knowledge of how tasks across jobs may be combined efficiently to produce final output.

${ }^{6}$ The idea that the employer requires workers to attain knowledge of the inputs and abilities of work colleagues as well as of the interlocking configurations of the company's production and administrative sections have been variously incorporated in labor research (Mailath and Postlethwaite, 1990; Chillemi and Gui, 1997).
} 
difficult to quantify and compensate, such as the development of interpersonal skills

(Prendergast, 1993). Such promotion processes are aided and abetted if there are some common task requirements in the leaving job and the new job. However, the accrual of task specific human capital within jobs will, at least in part, be lost if job changes take place. This does not preclude internal job moves, however. For example, performance within a given job may be used by the employer to signal general ability (Baker, Gibbs and Holmstrom, 1994) in which case workers exhibiting the greatest proficiency in developing their on-the-job skills would be promoted to higher level jobs involving higher level specific tasks.

Much of the foregoing discussion points to the need to investigate the joint contributions of employer tenure and job tenure to wage outcomes. While the literature overwhelmingly supports an expectation that wages rise with employer tenure, the contribution of job tenure within this wage process is less well explored. Conditional on employer tenure, increased proficiency in the execution of job tasks as job spells increase, resulting in the accrual of jobtask specific human capital, represents a positive expected return to job tenure. However, if proficiency in job tasks signals ability and encourages the employer to promote more able workers to higher-level jobs relatively early in their job tenure, this may produce a negative relationship between job tenure and wages. ${ }^{7}$ In essence, less able workers are selected to work for longer job spells at lower job levels. ${ }^{8}$

\section{Data}

The NESPD comprises a 1\% random sample of the entire British workforce. All individuals are allocated a National Insurance (NI) number on reaching the minimum school

\footnotetext{
${ }^{7}$ Waldman (1984) presents a model in which asymmetric information reduces the incentive for firms to promote their best workers; DeVaro and Waldman (2012) show that this effect is less important for more highly educated workers.

${ }^{8}$ This latter outcome is weakened or even reversed if performance across job holders exhibits low variation. In the extreme case where job holders are equally able, a seniority-based job promotion system is more likely (Carmichael (1983)).
} 
leaving age and the NESPD sample is selected on the basis of a given pair of digits within the NI number sequence. Employers are legally required to fill in a short questionnaire on sampled individuals that relates to a specific week in April. Wages and hours data are taken directly from company payrolls and are considered to be very accurate. Concentrating on full-time males and females in single jobs, we use the standard hourly wage as our pay measure, defined as "gross weekly earnings divided by normal basic hours for employees whose pay for the period was not affected by absence." We deflate this measure using the Retail Prices Index.

Employers are asked to indicate whether the employee has remained in the current job for more than 12 months and this allows us to distinguish between job stayers and job movers. However, for the period 1975 to 2001, the NESPD does not allow us directly to distinguish between within- and between- company job moves. In order to make this separation, we adopt the procedure earlier carried out by Devereux and Hart (2006) and Hart and Roberts (2011). We classify a within-company job mover as someone whose job move did not involve changing (a) geographical location and/or (b) 1-digit industrial classification ${ }^{9}$ and/or (c) public and private sector employment. For criterion (a) we use regional boundaries that define 97 local authority geographical areas. We are able to check the degree of accuracy of our estimated internal/external mover distinctions because, from 2002, the Office for National Statistics in its Annual Survey of Hours and Earnings (ASHE) provides company markers in respect of the individuals recorded in our NESPD data. Results are reported, for the period 2002-2010, in Hart and Roberts (2011). Our methodology predicts

\footnotetext{
${ }^{9}$ The industrial classification was changed in 1982 and in 1996. In subsequent regressions, we drop these two years from the analysis.
} 
correctly with well over $80 \%$ accuracy for both internal and external movers and for both genders. $^{10}$

The NESPD is jobs based. Employers provide the employee's full job title, including job rank or grade, as well as a short description of the work involved. On the basis of the collected information, jobs are classified by the Office for National Statistics into standard 3digit occupation codes. At the points of within- and between- company job changes it can be established whether (i) an individual remained in a job that is highly related to their previous job or (ii) underwent a major change in job description. Examples of within- company job changes recorded under (i) include: moves from assistants (referred to as 'mates') to woodworkers to woodworkers ${ }^{11}$ and moves from coal mining laborers to face-trained coal mining workers. Examples of within- company job changes recorded under (ii) include: moves from electrical production fitter to marketing and sales manager ${ }^{12}$ and computer operator to biochemist.

Our period of study is 1975 to 2010. We report NESPD male and female sample sizes with respect to job spells and employer spells in Table 1 together with information on the average ages of individuals within the two types of spell length. ${ }^{13}$ For males, $5.1 \%$ of total employer observations involve a within-company job move compared with $5.9 \%$ for

\footnotetext{
${ }^{10}$ Additionally, we have estimated the return to both employer and job tenure for the 2002-2010 period using both our method of separating job from employer moves and using the employer identifiers included in the data. Reassuringly, the estimated tenure effects are very similar for the two methods. However, the standard errors are high because the study period is short.

${ }^{11}$ There are many examples of such moves spread over many job descriptions.

${ }^{12}$ Moves from hands-on production work to sales/management roles commonly occur. Other examples include tire and exhaust fitter to garage manager and chefs/cooks to restaurant and catering managers.

${ }^{13}$ There are more job spell observations than employer spell observations. The latter are predicated on a marker indicating when a given individual has changed company. But we can also make use of individuals' job spells within companies for which we have no start date and, therefore, no employer spell coverage. In total, we have $33 \%(26 \%)$ more male (female) job spell observations than employer spell observations. Consequently, in Table 1 we report job spells' statistics for our full NESPD male and female samples as well as for job spells that match our employer spells samples.
} 
females. Within employer spells, $86.9 \%$ male (85.6\% female) workers are observed in a single job, $10.1 \%(11 \%)$ in 2 jobs, and $3 \%(3.4 \%)$ in 3 or more jobs.

\section{Wages and returns to tenure}

In the absence of statistics on pre-work education in the NESPD, we cannot calculate worker labor market experience for our complete data and so we use age as a proxy. For notational simplicity, we explain the methods used in the paper using simple linear constructs. In our actual regressions, we use quartic functions of age, employer tenure and job tenure. ${ }^{14}$

(a) Estimating the returns to tenure with employer

To start with, we follow the literature and treat tenure as employer-specific. Our general employer spell estimating equation takes the form

(1) $w_{i t}=\beta_{1} A_{i t}+\beta_{2} E_{i t}+Z_{i t} \theta+u_{i}+v_{i j}+e_{i t}$

where, for individual $i$ and time $t, w$ is the log real standard hourly wage, $A$ is age, $E$ is employer tenure, and $Z$ are controls consisting of year dummies, 97 local authority area dummies, 9 one-digit industries, and a dummy indicating whether or not collective bargaining applies to wage setting. The error includes an individual fixed component $\left(u_{i}\right)$, a job-match fixed component $\left(v_{i j}\right)$, and a transitory component $\left(e_{i t}\right)$.

The individual-specific component reflects unobserved time-invariant characteristics of the individual while the job-match fixed component represents the unknown quality of the match between employer and employee. The estimation problem arises because each of the

\footnotetext{
${ }^{14}$ So as not to restrict the wage response in the first year of each spell to the quartic specification of the tenure profile, Altonji and Shakotko (1987) add a dummy variable that takes the value of 1 in the first year and 0 thereafter. In the event, such dummies make negligible differences to our various results and they are excluded from all reported regressions.
} 
error components is potentially correlated with experience and tenure. The individual effect could be correlated with tenure because higher ability workers may stay longer with particular employers. The job-match component should increase with age because of jobshopping. Additionally, the positive correlation between age and tenure imply that biases in one coefficient spill over to the other.

To assess potential biases, it is standard in the literature to consider an auxiliary regression for each error component:

$$
\begin{aligned}
& u_{i}=b_{1} A_{i t}+b_{2} E_{i t}+\varphi_{i t} \\
& v_{i j}=c_{1} A_{i t}+c_{2} E_{i t}+\omega_{i t}
\end{aligned}
$$

The probability limits of the OLS estimates from equation (1) then take the form that plim $\widehat{\beta_{1}}=\beta_{1}+b_{1}+c_{1}$ and plim $\widehat{\beta_{2}}=\beta_{2}+b_{2}+c_{2}$. It is straight-forward to derive expressions for $b_{1}, c_{1}, b_{2}, c_{2}$ but, without making unreasonable assumptions, the OLS biases to either coefficient cannot be signed.

We estimate equation (1) using three different methods. Detailed comparative discussion of these approaches can be found in Altonji and Williams (2005) and Williams (2009). The first method is OLS which, as described above, is likely to be biased due to unobserved individual and job match heterogeneity.

As one approach to tackling the endogeneity of tenure, we follow Altonji and Shakotko (1987) by instrumenting $E_{i t}$ using deviations from the mean value of the variable over the entire spell of the employee with the employer. That is, $E_{i t}$ is instrumented by $D E_{i t}=E_{i t}-\bar{E}_{l}$ where $\bar{E}_{i}$ is average tenure of worker $i$ over the spell with the current employer. This is referred to by them as the IV1 estimator. 
By construction, $D E_{i t}$ has zero mean within each employer-employee spell and hence it is orthogonal to both the individual-specific error component and the match-specific error component. However, as has been shown in the literature, this estimator may still produce a biased estimate of the return to tenure because tenure and age are correlated and there should be a positive correlation between age and the match-specific error component. This would cause the parameter on age to be biased up and the parameter on tenure to be biased down. So, while the IV1 estimator does not suffer bias due to unobserved individual heterogeneity, it may still be biased by job match heterogeneity.

As an alternative approach to countering likely problems with OLS estimation, we employ the two-step first difference (2SFD) estimator of Topel (1991). Here, wages are initially de-trended. ${ }^{15}$ Since the variables in the $Z$ matrix are time-invariant within employeremployee spells ${ }^{16}$, step 1 expresses an individual's within-company wage growth in terms of the change in tenure with the current employer, or

(2) $\Delta w_{i t}=B \Delta E_{i t}+\Delta e_{i t}$

where $\Delta$ denotes the first difference. Within an employer spell, age and tenure change identically in (2), and so $B$ represents the combined returns to age and employer tenure.

Step 2 is designed to isolate the tenure contribution. Current age during an employer spell can be expressed as $A_{i t} \equiv A 0 E_{i t}+E_{i t}$ where $A O E_{i t}$ is the individual's age at the start of the current employer spell. Substituting this identity into (1) and re-arranging gives

\footnotetext{
${ }^{15}$ Following Williams (2009), we detrend our NESPD wages using year dummies.

${ }^{16}$ There are instances where the data indicate a change of collective bargaining status within job spells or employer spells. We do not know whether these derive from within-company decisions and policy or from measurement error. We follow Abraham and Farber (1988) and Williams (2009) and treat an individual as covered by a collective bargaining agreement within a complete job or employer spell if the first and last observations and at least two-thirds of all observations report coverage. The equivalent rule is applied to the classification 'not-covered'.
} 
(3) $w_{i t}-\widehat{B} E_{i t}=\beta_{1}\left(A 0 E_{i t}\right)+Z_{i t} \theta+u_{i}+v_{i j}+e_{i t}$

where $\hat{B}=\widehat{\beta}_{1} \widehat{+\beta_{2}}$ is estimated from equation (2). From (3), we can obtain $\widehat{\beta_{1}}$ which is an estimate of the return to age at the outset of a company employment spell. An estimate of returns to tenure over the spell is then given by $\widehat{B}-\widehat{\beta_{1}} \cdot{ }^{17}$

We note that correlations between the error components in (3) and $A O E_{i t}$ may produce biases in the estimated tenure effects using this method (Topel, 1991). In particular, the age when starting the employer spell is likely to be positively correlated with the job match component and so cause an upward bias in the age parameter and a downward bias in the tenure parameter. On the other hand, initial age will tend to be negatively correlated with the individual-specific component as better workers are less likely to start with new employers at older ages. This will tend to bias down the age parameter and bias up the return to tenure.

\section{(b) Estimating the return to job tenure}

While the literature focuses on tenure with employer, as discussed above, it is also interesting to study the effect of tenure in particular jobs. A worker can have several different jobs with any one employer. We begin by replacing employer tenure with job tenure in equation (1). This implies that we treat job shopping within firms the same way as we treat job shopping in the general labor market. Unlike employer tenure, no part of the return to job tenure occurs because opportunities for promotions to better jobs arise over time with the firm.

Our job spell equation simply replaces $E_{i t}$ with $J_{i t}$

\footnotetext{
${ }^{17}$ In the full specification, the nonlinear age and tenure terms are estimated in (2). The resulting estimates are multiplied by their respective age and tenure terms and additionally subtracted from the wage in (3) in order to refine the estimates of $\beta_{1}$ and the other control variables.
} 
(4) $w_{i t}=\gamma_{1} A_{i t}+\gamma_{2} J_{i t}+Z_{i t} \theta+u_{i}+v_{i j}+e_{i t}$

where $J$ is job tenure.

Equation (1) includes the effects of promotions (and demotions) between successive within-company jobs while these are excluded from equation (4). So, if promotions dominate, we would anticipate that $\hat{\beta}_{2}>\hat{\gamma}_{2}$.

As before, in addition to OLS, we use the IV1 estimator of Altonji and Shakotko and Topel's 2SFD estimator. In the instrumental variable case (IV1), $J_{i t}$ is instrumented by using deviations from the mean value of the variable over the spell in the current job. That is, $J_{i t}$ is instrumented by $D J_{i t}=J_{i t}-\bar{J}_{l}$ where $\bar{J}_{i}$ is average tenure of worker $i$ over the spell in the current job.

Likewise, using the Topel approach, estimates of job tenure follow the same twostage procedure as in (2) and (3) where $E$ is replaced by $J$ and where $A 0 J$ stands for age at the start of each within-company job and replaces $A O E$. That is, we first estimate the combined effect of age and job tenure by doing a first differenced regression within job spells. Then, we regress the predicted starting wage in the job spell on age at the start of the spell to find the age effect.

(c) Estimating joint wage effects of employer spells and job spells

Our final specification includes both employer tenure and job tenure in the same regression. Combining (1) and (4) we have (once again abstracting from the non-linear age and tenure terms),

(5) $w_{i t}=\mu_{1} A_{i t}+\mu_{2} E_{i t}+\mu_{3} J_{i t}+Z_{i t} \theta+u_{i}+v_{i j}+e_{i t}$. 
Clearly, to identify this model we need there to be some employer spells in which there are two or more job spells. Such job changes within employer spells are quite common in our data.

The potential biases from OLS are once again quite complicated in this model. First, we would expect that, conditional on $J_{i t}$, both age and employer tenure are positively correlated with the job match-specific component as they respectively correlate with greater opportunities for job shopping in the labor market and in the particular firm. This will tend to bias down the effect of job tenure. Likewise, the error components may be correlated with unobserved individual heterogeneity. A particular problem that arises here is that better workers are more likely to be promoted faster in any particular firm. This implies that, conditional on employer tenure, job tenure is likely to be negatively correlated with ability and, so, the effect of job tenure will be biased down.

While there is no estimation method that can deal with all these issues, we implement an augmented version of IV1 to partially address them. ${ }^{18}$ Specifically, we instrument job tenure with its deviation from the within-job mean for the person and employer tenure with its deviation from the within-employer spell mean for the person. Once again, by construction, both these instruments are orthogonal to the individual-specific error component. This implies that, so long as ability is constant over time, faster promotions for more able workers will not cause bias. However, while $D J_{i t}$ is orthogonal to the job match specific error, $D E_{i t}$ is likely to be positively correlated as having more tenure with the employer improves the likelihood of finding a job within the firm that is a good match. Additionally, if ability can change over time, persons who are revealed to have high ability are likely to be promoted sooner to a higher-level job within the firm. Therefore, we expect

\footnotetext{
${ }^{18}$ We don't estimate equation (5) using the Topel approach as it is unclear how this method can be generalized to this specification.
} 
this estimator to be less biased than OLS but still to provide a downwardly-biased estimate of the return to job tenure. ${ }^{19}$

\section{Wage-tenure estimates}

Tables $2 \mathrm{a}$ and $2 \mathrm{~b}$ show our respective male and female wage-tenure estimates of equations (1) and (4) in which job spells and employer spells are entered separately. There are two sets of results with respect to job spells. First, we include all jobs whether or not we can identify the employer spell to which they belong. Second, we estimate regressions using job spells data that exactly match our employer spells data. ${ }^{20}$ This sample contains exactly the same observations as used in the employer tenure analysis and so any differences in the estimates must be due to the difference in specification.

All regressions are extended to include higher order age and tenure effects. We show estimates of linear and higher order tenure terms together with estimates of tenure effects after 2 years, 5 years, and 10 years of job and employer tenure. Male and female results share a feature in common with earlier studies. Within employer spells, OLS estimated wage returns are significantly larger than either IV1 or $2 \mathrm{SFD}^{21}$ estimates. The same is true in respect of our job spell estimates. By contrast, male IV1 and 2SFD estimates correspond closely. In the case of females, estimated IV1 returns to tenure are also generally similar to their 2SFD equivalents. However, in all regressions, the standard errors of the 2SFD

\footnotetext{
${ }^{19}$ Note that the method we use here is equivalent to that used by researchers who study the effect of industry tenure in addition to employer tenure and labor market experience (for example, Parent, 2000, and Williams 2009). Analogous to the issue we face here with IV1, they face the problem that greater years of industry experience increase the likelihood of finding a good job match, biasing up the effect of industry experience and biasing down the effect of employer tenure.

${ }^{20}$ See footnote 13 .

${ }^{21}$ We carried out Topel's simple test of bias from individual heterogeneity in the 2SFD estimation. This involves using current age as an instrument for age at employer- or job- start. This produced very little change to the results.
} 
estimator are much higher than those for IV1. For all estimated job-spell returns to tenure, very similar results are obtained whether based on the full sample of jobs or jobs that are strictly contained within our male and female employer-spell samples.

Because log differences approximate to percentage changes, Tables $2 \mathrm{a}$ and $2 \mathrm{~b}$ show that cumulative wage increases within employer spells after 10 years of tenure are approximately $15 \%$ for males (17\% for females) using IV1, and $17 \%$ for males ( $27 \%$ for females) using 2SFD. How do these compare with the existing company-based literature?

In Table 3 we compare our NESPD findings with those based on the U.S. Panel Study of Income Dynamics (PSID) male employer spell estimates. Altonji and Williams (2005) provide male PSID estimates. They show OLS, IV1 and 2SFD results in respect of a replicated sample of the Topel (1991) study, covering the years 1968 to 1983. Additionally, they show estimates based on a more recent sample, covering the years 1975-2001, a period we can match with NESPD. Comparing the 1975-2010 NESPD employer tenure cumulative returns over 2, 5 and 10 years with the equivalents based on the 1968-1983 PSID sample, we find that the OLS and IV1 estimates are quite similar while the NESPD 2SFD returns are considerably lower than the PSID returns. For the matching 1975-2001 period, the two data sources provide very similar estimates. ${ }^{22}$

Williams (2009) obtains OLS, IV1 and 2SFD male estimates for the UK covering the period 1991-2001. Estimation diverges from the present study in four main respects. First, it is based on a household panel, the British Household Panel Survey (BHPS), that contains self-reported household information on wages, employment histories and other variables. Second, the BHPS is relatively small: it covered roughly 5,500 households and 10,000 individual full respondents between 1991 and 2001. Williams' sample contains 2521 workers. Third, as in PSID-based studies, BHPS wage equations incorporate work experience

\footnotetext{
${ }^{22}$ Buchinsky et. al (2010) find much larger estimates of the return to tenure in the PSID. Their approach differs in that they explicitly model the participation and inter-firm mobility decisions.
} 
and employer tenure (as opposed to age and tenure here). Fourth, male workers in Williams' study are restricted to the private sector (as opposed to private and public sectors here). After 10 years of tenure, Williams' estimated employer spell cumulative tenure effects are 0.143 (OLS), 0.06 (IV1), and 0.106 (2SFD) compared to $0.295,0.146$ and 0.167 respectively in this study. Also using the BHPS, from 1991 to 1999, Dustman and Pereira (2008) obtain estimates close to Williams, with an OLS effect after 10 years of 0.088 and an IV1 effect of 0.054. These tenure estimates are less than half the size of those obtained using the NESPD and PSID. ${ }^{23}$

Of most importance to the present study are the relative estimated returns to tenure using job spells compared to employer spells. Tables $2 \mathrm{a}$ and $2 \mathrm{~b}$ show IV1 and 2SFD estimates of male and female cumulative wage returns to 5 and 10 years of job tenure and employer tenure. On average, estimated returns to employer tenure are roughly one-third larger than returns to job tenure. Differences reflect two within-company effects. First, $13.1 \%$ of males and $14.4 \%$ of females within employer spells in our data are observed to hold 2 or more jobs (see Table 1). Second, average real wage increases linked to internal job moves are more than double those of individuals who remain in the same job. We find from Table 4 that annual real wage changes associated with internal job moves average $12.7 \%$ for males and $12.8 \%$ for females. Respective average annual real wage increases of job stayers are less than half of internal movers at $5.3 \%$ and $5.5 \%$ for men and women respectively. ${ }^{24}$

\footnotetext{
${ }^{23}$ We re-estimated our equations based only on private sector employees. This slightly increased our various estimated returns to tenure. We also estimated returns over the 1991 to 2001 period with no essential changes to our tenure coefficients. Interestingly, Williams' (2009) estimates of 10-year wage-tenure effects are nearer to our job-spell estimates (see Table $2 a$ ). It may be the case that a significantly lower percentage of employees in the BHPS sample, compared to NESPD, report that they held more than one job with the same employer $(13.1 \%$ of males and $14.4 \%$ of females in our data - see Table 1) and/or it might be that average percentage real wage increases between internal jobs within employer spells (about $12.5 \%$ in our data - see Table 4) are lower in the BHPS sample.

${ }^{24}$ If we only study job stayers for whom we know employer tenure, these numbers rise slightly to $5.9 \%$ for both men and women.
} 
Comparable median wage changes, while significantly lower in absolute terms, display even larger relative differences.

The much larger returns for employer tenure compared to job tenure have implications for our interpretation of the employer tenure coefficients. It is unlikely that the differences can be explained by specific human capital accumulation as, if anything, we might expect human capital to be at least as much job-specific as employer-specific. Instead, it is consistent with the conclusion that a substantial component of the return to employer tenure arises from a process of internal job shopping that enables wage increases to occur through promotions and other movements to jobs that are a better match for the individual's skills.

Based on the OLS and IV1 estimators, equation (5) generalizes our approach by incorporating both job spells and employer spells. In Table 5 we show male and female estimates of the returns to employer tenure and job tenure. The controls are the same as the equivalent results based on separate spell lengths in Tables $2 \mathrm{a}$ and $2 \mathrm{~b}$. Significant positive returns to the length of employer tenure contrast with significant negative returns to the length of job tenure. As expected, within employer spells, longer jobs are associated with fewer job changes and, since workers gain on average by changing job, with lower wage returns.

Cumulative wage increments over various spell lengths are shown at the foot of the Table 5. We concentrate on the IV1 estimates. Not accounting for average lengths of withincompany job spells, a typical male worker experiences a $23 \%$ cumulative wage rise resulting from 10-years of tenure with the same employer. A comparable female employment spell produces a $26 \%$ rise. If this complete employer spell is undertaken within a single job then within-company net returns are reduced by about $10 \%$ for both male and female workers. If average job tenure is shorter, then the negative length-of-job influence is reduced. Thus, if 
internal jobs last on average for 5 years then overall employer returns are reduced by $7 \%$ for men and $8 \%$ for women. Short 2-year average job lengths, implying quite frequent internal job changes, produce respective reductions of about $3 \%$ and $4 \%$.

\section{Conclusions}

Wages rising with tenure are variously interpreted as resulting from firm-specific human capital investments, incentive pay schemes, insurance arrangements, and wage strategies designed to attract high ability workers. In these cases, tenure is appropriately measured in terms of employer spells. Since Becker (1962), however, specific human capital that accrues on the job has formed an integral part of the workplace human capital literature. We find that the choice between job spells and employer spells as the basis for estimating wage-tenure relationships involves significant differences in outcomes. Job spells consist

only of job stayers. Employer spells embrace both job stayers and job movers. Average wage changes associated with internal job moves are significantly different from comparable wage changes among job stayers.

We show that estimated returns to tenure based on employer spells are significantly larger than those based on job spells -- cumulative returns to employer tenure after 5 or 10 years are roughly one-third larger than returns to job tenure. Combining job and employer spells, we find that longer jobs, and therefore fewer expected internal job changes, are associated with lower wage returns. This finding is supportive of the proposition that proficiency in executing job tasks acts as a signal of ability resulting in more able workers being promoted to higher level jobs leaving less able workers to remain in lower level jobs for longer periods of job tenure. It is also consistent with within-firm job shopping where, over time, workers find better job matches within the firm. Any positive effects of job- 
specific human capital on wage growth within jobs are outweighed by the effect of job changes within firms. 


\section{References}

Abraham, Katherine G., and Henry S. Farber (1988): Returns to seniority in union and nonunion jobs: a new look at the evidence. Industrial and Labor Relations Review 42: 3-19.

Altonji, Joseph G., and Robert A. Shakotko (1987): Do wages rise with job seniority? Review of Economic Studies 54: 437-459.

Altonji, Joseph G., and Nicolas Williams (2005): Do wages rise with job seniority? A reassessment. Industrial and Labor Relations Review 58: 370-397.

Buchinsky, Moshe, Fougere, Denis, Kramarz Francis and Rusty Tchernis (2010): Interfirm Mobility, Wages, and the Return to Seniority and Experience in the United States. Review of Economic Studies 77: 972-1001.

Baker, George, Michael Gibbs, and Bengt Holmstrom (1994): The wage policy of a firm. Quarterly Journal of Economics 109: 921-955.

Becker, Gary S. (1962): Human capital: a theoretical analysis. Journal of Political Economy 70: 9-49.

Becker, Gary S., and George J. Stigler (1974): Law Enforcement, Malfeasance, and the Compensation of Enforcers. Journal of Legal Studies 3, 1-18.

Carmichael, Lorne (1983): Firm-specific human capital and promotion ladders. Bell Journal of Economics 14: 251-258.

Chillemi Ottorino, and Benedetto Gui (1997): Team human capital and worker mobility. Journal of Labor Economics 15: 567-585.

DeVaro Jed, and Michael Waldman (2012): The Signaling Role of Promotions: Further Theory and Empirical Evidence. Journal of Labor Economics 30: 91-147.

Devereux, Paul J., and Robert A. Hart (2006): Real wage cyclicality of job stayers, withincompany job movers, and between-company job movers. Industrial and Labor Relations Review 60: 105-119. 
Doeringer, Peter, and Michael Piore (1971): Internal labor markets and manpower analysis. Boston: D.C. Heath and Co.

Dustmann, Christian, and Sonia C. Pereira (2008): "Wage Growth and Job Mobility in the United Kingdom and Germany”, Industrial and Labor Relations Review, 61, 374-393.

Frank, R. H. and R. M. Hutchens (1993): Wages, Seniority and the Demand for Rising Consumption Profiles. Journal of Economic Behavior and Organisation, 21, pp. 25176.

Gibbons, Robert and Michael Waldman (2004): Task-specific human capital, American Economic Review Papers and Proceedings 94: 203-207.

Guasch, J. Luis and Andrew Weiss (1980): Wages as sorting mechanisms in competitive markets with asymmetric information: a theory of testing. Review of Economic Studies 47, 653-664.

Harris, Milton and Bengt Holmstrom (1982): A Theory of Wage Dynamics. Review of Economic Studies 49, 315-333.

Hart, Robert A., and J Elizabeth Roberts (2011): Job re-grading, real wages, and the cycle. IZA Discussion Paper \#5912.

Lazear, Edward P. (1979): Why is there Mandatory Retirement? Journal of Political Economy $87,1261-64$.

Lazear, Edward, P. (2009): Firm-specific human capital: a skill-weights approach. Journal of Political Economy, 117: 914-940..

Mailath, George J, and Andrew Postlethwaite (1990): Workers versus firms: bargaining over a firm's value. Review of Economic Studies 57: 369-380.

Parent, Daniel (2000): Industry-specific human capital - evidence from the National Longitudinal Survey of Youth and the Panel Study of Income Dynamics. Journal of Labor Economics 18, 306-323. 
Parsons, Donald 0. (1972): Specific human capital: an application to quit rates and layoff rates. Journal of Political Economy 80, 1120-1143.

Prendergast, Canice (1993): The role of promotion in inducing specific human capital acquisition, Quarterly Journal of Economics 108: 523-534.

Salop, Steven and Joanne Salop (1976): Self-Selection and Turnover in the Labor Market. Quarterly Journal of Economics 90, 619-27.

Topel, Robert (1991): Specific capital, mobility, and wages: wages rise with job seniority. Journal of Political Economy 99, 145-176.

Waldman, Michael. (1984). Job assignments, signalling, and efficiency. Rand Journal of Economics 15, no. 2:255-67.

Williams, Nicolas (2009): Seniority, experience, and wages in the UK. Labour Economics 16, 272-283. 
Table 1 Descriptive statistics: NESPD, 1975-2010

\begin{tabular}{|c|c|c|c|c|c|c|}
\hline & Men & & & Women & & \\
\hline & $\begin{array}{c}\text { Job spells } \\
\text { (full sample) }\end{array}$ & $\begin{array}{c}\text { Job spells } \\
\text { (employer } \\
\text { spells sample) }\end{array}$ & $\begin{array}{l}\text { Employer } \\
\text { spells }\end{array}$ & $\begin{array}{c}\text { Job spells } \\
\text { (full sample) }\end{array}$ & $\begin{array}{c}\text { Job spells } \\
\text { (employer } \\
\text { spells sample) }\end{array}$ & $\begin{array}{l}\text { Employer } \\
\text { spells }\end{array}$ \\
\hline $\begin{array}{l}\text { Average age, all workers (median } \\
\text { age) }\end{array}$ & $36.4(35)$ & $35.4(34)$ & $35.4(34)$ & $33.3(30)$ & $32.4(29)$ & $32.4(29)$ \\
\hline $\begin{array}{l}\text { Within-company job movers \% } \\
\text { share of total observations }\end{array}$ & - & - & 5.1 & - & - & 5.9 \\
\hline $\begin{array}{l}\% \text { of all within-company workers } \\
\text { who held } 1 \text { job }\end{array}$ & - & - & 86.9 & - & - & 85.6 \\
\hline $\begin{array}{l}\text { \% of all within-company workers } \\
\text { who held } 3 \text { jobs }\end{array}$ & - & - & 2.1 & - & - & 2.4 \\
\hline $\begin{array}{l}\% \text { of all within-company workers } \\
\text { who held }>3 \text { jobs }\end{array}$ & - & - & 0.9 & - & - & 1.0 \\
\hline Average length of spell & 2.6 & 2.5 & 2.9 & 2.4 & 2.3 & 2.8 \\
\hline
\end{tabular}


Table 2a Real wages and separate returns to employer tenure and job tenure: males, 1976-2010

\begin{tabular}{|c|c|c|c|c|c|c|c|c|c|}
\hline & \multicolumn{3}{|c|}{$\begin{array}{c}\text { Job Spells } \\
\text { (full sample) }\end{array}$} & \multicolumn{3}{|c|}{$\begin{array}{c}\text { Job Spells } \\
\text { (employer spells sample) }\end{array}$} & \multicolumn{3}{|c|}{ Employer Spells } \\
\hline & OLS & IV1 & 2SFD & OLS & IV1 & 2SFD & OLS & IV1 & 2SFD \\
\hline Tenure & $\begin{array}{c}0.0678 \\
(0.0012)\end{array}$ & $\begin{array}{c}0.0191 \\
(0.0014)\end{array}$ & $\begin{array}{c}0.0109 \\
(0.0080)\end{array}$ & $\begin{array}{c}0.0701 \\
(0.0014)\end{array}$ & $\begin{array}{c}0.0218 \\
(0.0016)\end{array}$ & $\begin{array}{c}0.0129 \\
(0.0093)\end{array}$ & $\begin{array}{c}0.0729 \\
(0.0012)\end{array}$ & $\begin{array}{c}0.0285 \\
(0.0015)\end{array}$ & $\begin{array}{c}0.0170 \\
(0.0092)\end{array}$ \\
\hline Tenure $^{2} / 10$ & $\begin{array}{l}-0.0701 \\
(0.0023)\end{array}$ & $\begin{array}{l}-0.0140 \\
(0.0025) \\
\end{array}$ & $\begin{array}{l}-0.0160 \\
(0.0015) \\
\end{array}$ & $\begin{array}{l}-0.0720 \\
(0.0029) \\
\end{array}$ & $\begin{array}{l}-0.0168 \\
(0.0030) \\
\end{array}$ & $\begin{array}{l}-0.0201 \\
(0.0019) \\
\end{array}$ & $\begin{array}{c}-0.0686 \\
(0.0023)\end{array}$ & $\begin{array}{l}-0.0222 \\
(0.0025) \\
\end{array}$ & $\begin{array}{l}-0.0245 \\
(0.0017) \\
\end{array}$ \\
\hline Tenure $3 / 100$ & $\begin{array}{c}0.0312 \\
(0.0016) \\
\end{array}$ & $\begin{array}{c}0.0062 \\
(0.0016) \\
\end{array}$ & $\begin{array}{c}0.0099 \\
(0.0014) \\
\end{array}$ & $\begin{array}{c}0.0318 \\
(0.0020) \\
\end{array}$ & $\begin{array}{c}0.0074 \\
(0.0020) \\
\end{array}$ & $\begin{array}{c}0.0134 \\
(0.0017) \\
\end{array}$ & $\begin{array}{c}0.0295 \\
(0.0014) \\
\end{array}$ & $\begin{array}{c}0.0097 \\
(0.0015) \\
\end{array}$ & $\begin{array}{c}0.0154 \\
(0.0015) \\
\end{array}$ \\
\hline Tenure $^{4} / 1000$ & $\begin{array}{l}-0.0048 \\
(0.0003)\end{array}$ & $\begin{array}{l}-0.0010 \\
(0.0003)\end{array}$ & $\begin{array}{l}-0.0019 \\
(0.0004)\end{array}$ & $\begin{array}{l}-0.0048 \\
(0.0004)\end{array}$ & $\begin{array}{l}-0.0012 \\
(0.0004)\end{array}$ & $\begin{array}{l}-0.0027 \\
(0.0004)\end{array}$ & $\begin{array}{l}-0.0043 \\
(0.0003)\end{array}$ & $\begin{array}{l}-0.0015 \\
(0.0003)\end{array}$ & $\begin{array}{l}-0.0030 \\
(0.0003)\end{array}$ \\
\hline Observations & 937334 & 937334 & $\begin{array}{r}491544 \\
668543 \\
\end{array}$ & 704641 & 704641 & $\begin{array}{l}354130 \\
488019\end{array}$ & 704641 & 704641 & $\begin{array}{l}380772, \\
507868\end{array}$ \\
\hline & \multicolumn{9}{|c|}{ Estimated effects of tenure } \\
\hline 2 years of tenure & $\begin{array}{c}0.1099 \\
(0.0021) \\
\end{array}$ & $\begin{array}{c}0.0330 \\
(0.0025) \\
\end{array}$ & $\begin{array}{c}0.0214 \\
(0.0159) \\
\end{array}$ & $\begin{array}{c}0.1138 \\
(0.0026) \\
\end{array}$ & $\begin{array}{c}0.0374 \\
(0.0029) \\
\end{array}$ & $\begin{array}{c}0.0253 \\
(0.0185) \\
\end{array}$ & $\begin{array}{c}0.1206 \\
(0.0022) \\
\end{array}$ & $\begin{array}{c}0.0489 \\
(0.0026) \\
\end{array}$ & $\begin{array}{c}0.0334 \\
(0.0183) \\
\end{array}$ \\
\hline 5 years of tenure & $\begin{array}{c}0.1996 \\
(0.0062)\end{array}$ & $\begin{array}{c}0.0675 \\
(0.0070) \\
\end{array}$ & $\begin{array}{c}0.0535 \\
(0.0398) \\
\end{array}$ & $\begin{array}{c}0.2071 \\
(0.0076)\end{array}$ & $\begin{array}{c}0.0752 \\
(0.0084) \\
\end{array}$ & $\begin{array}{c}0.0632 \\
(0.0463) \\
\end{array}$ & $\begin{array}{c}0.2272 \\
(0.0062) \\
\end{array}$ & $\begin{array}{c}0.0984 \\
(0.0073) \\
\end{array}$ & $\begin{array}{c}0.0836 \\
(0.0458) \\
\end{array}$ \\
\hline 10 years of tenure & $\begin{array}{c}0.2409 \\
(0.0217)\end{array}$ & $\begin{array}{c}0.1027 \\
(0.0234)\end{array}$ & $\begin{array}{c}0.1069 \\
(0.0797)\end{array}$ & $\begin{array}{c}0.2504 \\
(0.0268)\end{array}$ & $\begin{array}{c}0.1111 \\
(0.0282)\end{array}$ & $\begin{array}{c}0.1264 \\
(0.0926)\end{array}$ & $\begin{array}{c}0.2950 \\
(0.0208)\end{array}$ & $\begin{array}{c}0.1461 \\
(0.0234)\end{array}$ & $\begin{array}{c}0.1672 \\
(0.0917)\end{array}$ \\
\hline
\end{tabular}

Notes: Dependent variable is the log of the standard hourly wage (i.e. excluding overtime). Robust (White) standard errors in parentheses. All regression equations include quartic terms in tenure and age as well as local authority area, industry, and collective bargaining dummies. OLS and IV1 regressions also include year dummies. In the 2SFD regressions, wages are initially de-trended using year dummies estimated from within the sample. 
Table 2b Real wages and separate returns to employer tenure and job tenure: females, 1976-2010

\begin{tabular}{|c|c|c|c|c|c|c|c|c|c|}
\hline & \multicolumn{3}{|c|}{$\begin{array}{c}\text { Job Spells } \\
\text { (full sample) }\end{array}$} & \multicolumn{3}{|c|}{$\begin{array}{c}\text { Job Spells } \\
\text { (employer spells sample) }\end{array}$} & \multicolumn{3}{|c|}{ Employer Spells } \\
\hline & OLS & IV1 & 2SFD & OLS & IV1 & 2SFD & OLS & IV1 & 2SFD \\
\hline Tenure & $\begin{array}{c}0.0616 \\
(0.0013)\end{array}$ & $\begin{array}{c}0.0191 \\
(0.0016)\end{array}$ & $\begin{array}{c}0.0192 \\
(0.0082)\end{array}$ & $\begin{array}{c}0.0631 \\
(0.0016)\end{array}$ & $\begin{array}{c}0.0304 \\
(0.0019)\end{array}$ & $\begin{array}{c}0.0215 \\
(0.0094)\end{array}$ & $\begin{array}{c}0.0696 \\
(0.0014)\end{array}$ & $\begin{array}{c}0.0297 \\
(0.0016)\end{array}$ & $\begin{array}{c}0.0273 \\
(0.0093) \\
\end{array}$ \\
\hline Tenure $^{2} / 10$ & $\begin{array}{l}-0.0609 \\
(0.0027)\end{array}$ & $\begin{array}{l}-0.0124 \\
(0.0031)\end{array}$ & $\begin{array}{l}-0.0251 \\
(0.0018)\end{array}$ & $\begin{array}{l}-0.0616 \\
(0.0034)\end{array}$ & $\begin{array}{l}-0.0130 \\
(0.0038)\end{array}$ & $\begin{array}{l}-0.0290 \\
(0.0022)\end{array}$ & $\begin{array}{l}-0.0623 \\
(0.0026)\end{array}$ & $\begin{array}{l}-0.0202 \\
(0.0030)\end{array}$ & $\begin{array}{l}-0.0330 \\
(0.0019)\end{array}$ \\
\hline Tenure $3 / 100$ & $\begin{array}{c}0.0291 \\
(0.0019) \\
\end{array}$ & $\begin{array}{c}0.0063 \\
(0.0021)\end{array}$ & $\begin{array}{c}0.0125 \\
(0.0017)\end{array}$ & $\begin{array}{c}0.0294 \\
(0.0025) \\
\end{array}$ & $\begin{array}{c}0.0066 \\
(0.0027) \\
\end{array}$ & $\begin{array}{c}0.0153 \\
(0.0023) \\
\end{array}$ & $\begin{array}{c}0.0271 \\
(0.0017) \\
\end{array}$ & $\begin{array}{c}0.0090 \\
(0.0019) \\
\end{array}$ & $\begin{array}{c}0.0170 \\
(0.0018) \\
\end{array}$ \\
\hline Tenure $^{4} / 1000$ & $\begin{array}{l}-0.0047 \\
(0.0004)\end{array}$ & $\begin{array}{l}-0.0011 \\
(0.0004)\end{array}$ & $\begin{array}{l}-0.0020 \\
(0.0005)\end{array}$ & $\begin{array}{l}-0.0048 \\
(0.0005)\end{array}$ & $\begin{array}{l}-0.0011 \\
(0.0006)\end{array}$ & $\begin{array}{l}-0.0026 \\
(0.0006) \\
\end{array}$ & $\begin{array}{l}-0.0041 \\
(0.0004)\end{array}$ & $\begin{array}{l}-0.0014 \\
(0.0004) \\
\end{array}$ & $\begin{array}{l}-0.0028 \\
(0.0005) \\
\end{array}$ \\
\hline Observations & 574956 & 574956 & $\begin{array}{l}294709 \\
410713\end{array}$ & 454832 & 454832 & $\begin{array}{l}224169 \\
315624\end{array}$ & 454832 & 454832 & $\begin{array}{l}245360, \\
332525\end{array}$ \\
\hline & \multicolumn{9}{|c|}{ Estimated effects of tenure } \\
\hline 2 years of tenure & $\begin{array}{c}0.1011 \\
(0.0024)\end{array}$ & $\begin{array}{c}0.0337 \\
(0.0028)\end{array}$ & $\begin{array}{c}0.0378 \\
(0.0164)\end{array}$ & $\begin{array}{c}0.1038 \\
(0.0029)\end{array}$ & $\begin{array}{c}0.0361 \\
(0.0034)\end{array}$ & $\begin{array}{c}0.0425 \\
(0.0187)\end{array}$ & $\begin{array}{c}0.1162 \\
(0.0024)\end{array}$ & $\begin{array}{c}0.0520 \\
(0.0030)\end{array}$ & $\begin{array}{c}0.0540 \\
(0.0185)\end{array}$ \\
\hline 5 years of tenure & $\begin{array}{c}0.1892 \\
(0.0070) \\
\end{array}$ & $\begin{array}{c}0.0716 \\
(0.0083)\end{array}$ & $\begin{array}{c}0.0945 \\
(0.0409) \\
\end{array}$ & $\begin{array}{c}0.1951 \\
(0.0087) \\
\end{array}$ & $\begin{array}{c}0.0771 \\
(0.0101) \\
\end{array}$ & $\begin{array}{c}0.1063 \\
(0.0468) \\
\end{array}$ & $\begin{array}{c}0.2227 \\
(0.0071) \\
\end{array}$ & $\begin{array}{c}0.1082 \\
(0.0084) \\
\end{array}$ & $\begin{array}{r}0.1350 \\
(0.0463) \\
\end{array}$ \\
\hline 10 years of tenure & $\begin{array}{c}0.2511 \\
(0.0252) \\
\end{array}$ & $\begin{array}{c}0.1189 \\
(0.0289)\end{array}$ & $\begin{array}{c}0.1890 \\
(0.0818)\end{array}$ & $\begin{array}{c}0.2613 \\
(0.0321) \\
\end{array}$ & $\begin{array}{c}0.1289 \\
(0.0358) \\
\end{array}$ & $\begin{array}{c}0.2126 \\
(0.0937) \\
\end{array}$ & $\begin{array}{c}0.2993 \\
(0.0246) \\
\end{array}$ & $\begin{array}{c}0.1701 \\
(0.0282) \\
\end{array}$ & $\begin{array}{c}0.2701 \\
(0.0925) \\
\end{array}$ \\
\hline
\end{tabular}

Notes: Dependent variable is the log of the standard hourly wage (i.e. excluding overtime). Robust (White) standard errors in parentheses. All regression equations include quartic terms in tenure and age as well as local authority area, industry, and collective bargaining dummies. OLS and IV1 regressions also include year dummies. In the 2SFD regressions, wages are initially de-trended using year dummies estimated from within the sample. 
Table 3 Estimated wage returns to male tenure within employer spells:

NESPD and PSID compared

\begin{tabular}{|c|c|c|c|c|c|c|}
\hline & \multicolumn{3}{|c|}{ NESPD $^{1}$} & \multicolumn{3}{|c|}{ PSID $^{2}$} \\
\hline & \multicolumn{3}{|c|}{$1975-2010$} & \multicolumn{3}{|c|}{1968 - 1983} \\
\hline & OLS & IV1 & 2SFD & OLS & IV1 & 2SFD \\
\hline 2 years of tenure & $\begin{array}{c}0.1206 \\
(0.0022)\end{array}$ & $\begin{array}{c}0.0489 \\
(0.0026)\end{array}$ & $\begin{array}{c}0.0334 \\
(0.0183)\end{array}$ & $\begin{array}{c}0.0923 \\
(0.0127)\end{array}$ & $\begin{array}{c}0.0527 \\
(0.0103)\end{array}$ & $\begin{array}{c}0.1033 \\
(0.0132)\end{array}$ \\
\hline 5 years of tenure & $\begin{array}{c}0.2272 \\
(0.0062)\end{array}$ & $\begin{array}{c}0.0984 \\
(0.0073)\end{array}$ & $\begin{array}{c}0.0836 \\
(0.0458)\end{array}$ & $\begin{array}{c}0.1881 \\
(0.0219)\end{array}$ & $\begin{array}{c}0.0973 \\
(0.0194)\end{array}$ & $\begin{array}{c}0.1950 \\
(0.0237)\end{array}$ \\
\hline 10 years of tenure & $\begin{array}{c}0.2950 \\
(0.0208)\end{array}$ & $\begin{array}{c}0.1461 \\
(0.0234)\end{array}$ & $\begin{array}{c}0.1672 \\
(0.0917)\end{array}$ & $\begin{array}{c}0.2732 \\
(0.0250)\end{array}$ & $\begin{array}{c}0.1188 \\
(0.0277)\end{array}$ & $\begin{array}{c}0.2474 \\
(0.0287)\end{array}$ \\
\hline & \multicolumn{3}{|c|}{$1975-2001$} & \multicolumn{3}{|c|}{1975 - 2001} \\
\hline 10 years of tenure & $\begin{array}{c}0.2895 \\
(0.0392)\end{array}$ & $\begin{array}{c}0.1502 \\
(0.0438)\end{array}$ & $\begin{array}{c}0.2927 \\
(0.0880)\end{array}$ & $\begin{array}{c}0.3920 \\
(0.0188)\end{array}$ & $\begin{array}{c}0.1583 \\
(0.0180)\end{array}$ & $\begin{array}{c}0.2466 \\
(0.0230)\end{array}$ \\
\hline
\end{tabular}

1 NESPD: dependent variable is log of the real standard hourly wage.

2 PSID: dependent variable is log of real annual earnings divided by annual hours. Data taken from Altonji and Williams (2005, Tables 2 and 6). 
Table 4 Real wage changes and within-company job moves: NESPD, 1976 - 2010

\begin{tabular}{|l|c|c|}
\hline \multicolumn{1}{|c|}{} & Males & Females \\
\hline $\begin{array}{l}\text { Average \% real wage increases of stayers } \\
\text { within jobs (median) }\end{array}$ & $5.3(1.9)$ & $5.5(2.8)$ \\
\hline $\begin{array}{l}\text { Average \% real wage increases of stayers } \\
\text { within companies (median) }\end{array}$ & $5.9(2.2)$ & $5.9(3.1)$ \\
\hline $\begin{array}{l}\text { Average \% real wage increases of within- } \\
\text { company job movers (median) }\end{array}$ & $12.7(7.2)$ & $12.8(8.4)$ \\
\hline
\end{tabular}


Table 5 Real wages and joint returns to employer tenure and job tenure, 1976-2010

\begin{tabular}{|c|c|c|c|c|}
\hline & OLS & IV1 & OLS & IV1 \\
\hline & \multicolumn{2}{|c|}{ MALES } & \multicolumn{2}{|c|}{ FEMALES } \\
\hline Employer tenure & $\begin{array}{c}0.0804 \\
(0.0022)\end{array}$ & $\begin{array}{c}0.0459 \\
(0.0027)\end{array}$ & $\begin{array}{c}0.0825 \\
(0.0021)\end{array}$ & $\begin{array}{c}0.0526 \\
(0.0028)\end{array}$ \\
\hline (Employer tenure) $^{2} / 10$ & $\begin{array}{c}-0.0670 \\
(0.0034)\end{array}$ & $\begin{array}{l}-0.0369 \\
(0.0041)\end{array}$ & $\begin{array}{c}-0.0737 \\
(0.0038)\end{array}$ & $\begin{array}{c}-0.0424 \\
(0.0047)\end{array}$ \\
\hline (Employer tenure) $)^{3} / 100$ & $\begin{array}{c}0.0286 \\
(0.0020)\end{array}$ & $\begin{array}{c}0.0167 \\
(0.0023)\end{array}$ & $\begin{array}{c}0.0306 \\
(0.0024)\end{array}$ & $\begin{array}{c}0.0184 \\
(0.0028)\end{array}$ \\
\hline$(\text { Employer tenure) })^{4} / 1000$ & $\begin{array}{c}-0.0042 \\
(0.0004)\end{array}$ & $\begin{array}{l}-0.0025 \\
(0.0004)\end{array}$ & $\begin{array}{l}-0.0045 \\
(0.0005)\end{array}$ & $\begin{array}{l}-0.0029 \\
(0.0005)\end{array}$ \\
\hline Job tenure & $\begin{array}{l}-0.0066 \\
(0.0022)\end{array}$ & $\begin{array}{c}-0.0199 \\
(0.0029)\end{array}$ & $\begin{array}{c}-0.0144 \\
(0.0024)\end{array}$ & $\begin{array}{l}-0.0269 \\
(0.0031)\end{array}$ \\
\hline$(\text { Job tenure })^{2} / 10$ & $\begin{array}{l}-0.0073 \\
(0.0041)\end{array}$ & $\begin{array}{c}0.0165 \\
(0.0048)\end{array}$ & $\begin{array}{c}0.0096 \\
(0.0048)\end{array}$ & $\begin{array}{c}0.0249 \\
(0.0057)\end{array}$ \\
\hline${\text { (Job tenure })^{3} / 100}$ & $\begin{array}{c}0.0035 \\
(0.0026)\end{array}$ & $\begin{array}{c}-0.0082 \\
(0.0029)\end{array}$ & $\begin{array}{c}-0.0014 \\
(0.0033)\end{array}$ & $\begin{array}{l}-0.0105 \\
(0.0037)\end{array}$ \\
\hline$(\text { Job tenure })^{4} / 1000$ & $\begin{array}{c}-0.0005 \\
(0.0005)\end{array}$ & $\begin{array}{c}0.0012 \\
(0.0006)\end{array}$ & $\begin{array}{c}-0.0001 \\
(0.0007)\end{array}$ & $\begin{array}{c}0.0016 \\
(0.0008)\end{array}$ \\
\hline \multirow[t]{2}{*}{ Observations } & 704394 & 704394 & 454832 & 454832 \\
\hline & \multicolumn{4}{|c|}{ Estimated effects of tenure } \\
\hline 5 years employer tenure & $\begin{array}{c}0.2674 \\
(0.0100) \\
\end{array}$ & $\begin{array}{c}0.1562 \\
(0.0129) \\
\end{array}$ & $\begin{array}{c}0.2637 \\
(0.0107) \\
\end{array}$ & $\begin{array}{c}0.1784 \\
(0.0139) \\
\end{array}$ \\
\hline 10 years employer tenure & $\begin{array}{c}0.3774 \\
(0.0312)\end{array}$ & $\begin{array}{c}0.2308 \\
(0.0389)\end{array}$ & $\begin{array}{c}0.3491 \\
(0.0355)\end{array}$ & $\begin{array}{c}0.2581 \\
(0.0438)\end{array}$ \\
\hline 2 years job tenure & $\begin{array}{c}-0.0157 \\
(0.0040)\end{array}$ & $\begin{array}{l}-0.0338 \\
(0.0053)\end{array}$ & $\begin{array}{l}-0.0250 \\
(0.0043)\end{array}$ & $\begin{array}{l}-0.0446 \\
(0.0057)\end{array}$ \\
\hline 5 years job tenure & $\begin{array}{c}-0.0469 \\
(0.0114)\end{array}$ & $\begin{array}{c}-0.0676 \\
(0.0144)\end{array}$ & $\begin{array}{l}-0.0496 \\
(0.0127)\end{array}$ & $\begin{array}{c}-0.0842 \\
(0.0160) \\
\end{array}$ \\
\hline 10 years job tenure & $\begin{array}{c}-0.1083 \\
(0.0384)\end{array}$ & $\begin{array}{l}-0.1036 \\
(0.0453)\end{array}$ & $\begin{array}{c}-0.0616 \\
(0.0447)\end{array}$ & $\begin{array}{c}-0.1082 \\
(0.0534)\end{array}$ \\
\hline
\end{tabular}

Notes: Dependent variable is the log of the standard hourly wage (i.e. excluding overtime). Robust (White) standard errors in parenthesis. Regressions include year, area, industry, and collective bargaining dummies. 